\title{
PENCEGAHAN PENYAKIT ANEMIA PADA REMAJA DENGAN PEMERIKSAAN HEMOGLOBIN AWAL PADA SANTRI PONDOK PESANTREN THAWALIB SRIWIJAYA PALEMBANG
}

\author{
Tia Sabrina ${ }^{1 *}$, Rima Zanaria ${ }^{2}$, Masayu Farah Diba $^{3} \&$ Tyas Hestiningsih ${ }^{4}$ \\ 1,2,3 Bagian Mikrobiologi Klinik, FK, Universitas Sriwijaya \\ Jl. Prof. Dr. Moh. Ali Komplek RSMH Palembang, Indonesia \\ *Korespondensi: tiasabrina.ts@fk.unsri.ac.id
}

\begin{abstract}
Abstrak
Anemia merupakan masalah gizi yang paling sering dijumpai di dunia. Berdasarkan Laporan Nasional Riskesdas 2018, angka kejadian anemia pada remaja usia 15-24 tahun sebesar 32\%. Angka ini termasuk tinggi untuk masalah kesehatan yang terkait gizi pada remaja. Masa remaja merupakan masa pertumbuhan yang membutuhkan asupan gizi tinggi, baik berupa energi, protein dan zat-zat gizi lainnya dan kebutuhan zat besi meningkat pada remaja dapat menyebabkan anemia pada remaja. Tujuan dari kegiatan pengabdian ini adalah untuk mencegah penyakit anemia dengan pemeriksaan hemoglobin awal pada santri Pondok Pesantren (Ponpes) Thawalib Sriwijaya Palembang. Sasaran pengabdian ini adalah santri-santri pondok pesantren berusia 12-18 tahun, sebanyak 46 orang. Kegiatan dilakukan dalam bentuk ceramah tentang anemia, diskusi dan pemeriksaan kadar hemoglobin. Dari hasil pemeriksaan didapatkan bahwa 14 santri (30\%) yang memiliki gejala anemia karena kadar hemoglobin kurang dari normal, yaitu 13 santri laki-laki yang memiliki kadar hemoglobin $<13 \mathrm{~g} / \mathrm{dl}$ dan 1 santri perempuan yang memiliki kadar hemoglobin $<12 \mathrm{gr} / \mathrm{dl}$.
\end{abstract}

Kata kunci: anemia, remaja, hemoglobin

\section{ANALISIS SITUASI}

Secara global, anemia merupakan masalah gizi yang paling sering dijumpai dan mempengaruhi sekitar 2 miliar populasi di dunia yang berakibat pada perkembangan sosial dan ekonomi (Ghaffar and Waqar, 2018). Di Indonesia, anemia juga menjadi salah satu masalah kesehatan utama yang dihadapi oleh remaja di Indonesia (Briawan, 2014).

Di dunia, prevalensi anemia pada remaja sekitar 27\% di negara berkembang dan $6 \%$ di negara maju (Suryani, Hafiani and Junita, 2017). Berdasarkan Laporan Nasional Riskesdas 2018, angka kejadian anemia pada remaja usia 15-24 tahun sebesar 32\% 
(Kemkes, 2018). Angka ini termasuk tinggi untuk masalah kesehatan yang terkait gizi pada remaja.

Penyebab utama masalah anemia pada remaja adalah defisiensi besi. Pola asupan makanan yang diperoleh merupakan penyebab defisiensi besi yang paling sering dialami oleh sebagian besar remaja (WHO, 2006). Masa remaja merupakan masa pertumbuhan yang membutuhkan asupan gizi tinggi, baik berupa energi, protein dan zat-zat gizi lainnya. Kebutuhan zat besi meningkat pada remaja dapat terjadi karena sedang terjadi pematangan seksual dan pada remaja putri kebutuhan zat besi lebih tinggi daripada remaja laki-laki karena dibutuhkan untuk mengganti zat besi yang hilang pada saat menstruasi (Permaesih and Herman, 2005). Anemia dapat berdampak pada penurunan konsentrasi belajar yang berakibat prestasi belajar rendah, cepat lelah, daya tahan tubuh berkurang, penurunan produktivitas kerja, serta berpengaruh pada kondisi fisik seseorang (World Health Organization and others, 2001).

Deteksi dini kejadian anemia pada remaja merupakan salah satu tindakan pencegahan anemia yang dapat dilakukan sedini mungkin. Pemeriksaan hemogloblin awal pada remaja dapat digunakan untuk mengetahui status haemoglobin pada remaja. Pada remaja yang telah diketahui menderita anemia secara awal dapat diberikan perlakuan khusus agar tidak berkepanjangan. Tindakan yang dapat dilakukan dapat berupa perubahan pola asupan makanan atau pemberian Tablet Tambah Darah (TTD).

Pondok Pesantren Thawalib Sriwijaya Palembang adalah salah satu pusat pendidikan berbasis agama Islam yang beralamat di Jl. Talang Kemang Kecamatan Gandus Palembang. Pondok pesantren ini mendidik santri-santri usia remaja, sekitar usia 1218 tahun, yang tinggal di dalam asrama. Keadaan gizi asrama berpengaruh pada tingkat gizi para santri yang ada di dalamnya. Pola makan yang diterapkan di asrama mempunyai efek yang besar pada tingkat kecukupan gizi para santri. Tingkat asupan gizi yang cukup berpengaruh pada kualitas pendidikan yang dijalani oleh santri. Oleh karena itu, pemeriksaan haemoglobin awal pada remaja khusunya santri di Pondok Pesantren Thawalib Sriwijaya Palembang sangat penting dalam upaya pencegahan penyakit anemia pada remaja.

\section{METODE PELAKSANAAN}

Kegiatan pengabdian kepada masyarakat ini dilaksanakan di Pondok Pesantren Thawalib Sriwijaya Palembang pada tanggal 27 Oktober 2020 dengan khalayak sasaran kegiatan ini adalah santri-santri pondok pesantren berusia 12-18 tahun, sebanyak 46 orang.

Model kegiatan pengabdian masyarakat ini menggunakan model pemberdayaan. Model ini mengumpulkan khalayak sasaran untuk dilakukan pembinaan terkait 
peningkatan pengetahuan dan kesadaran akan dampak penyakit anemia. Adapun metode kegiatan yang digunakan yaitu:

1. Ceramah bervariasi.

Metode ini dipilih untuk menyampaikan konsep-konsep yang penting untuk dimengerti dan dikuasai oleh peserta pelatihan. Penggunaan metode ini dengan pertimbangan bahwa metode ceramah yang dikombinasikan dengan membagikan materi kepada santri seperti instrumen dan lainnya serta tampilan power point dilengkapi dengan gambar-gambar, animasi dan display dapat memberikan materi yang relatif banyak secara padat, cepat dan mudah.

2. Diskusi

Metode ini dipilih untuk melengkapi metode ceramah. Diskusi dilakukan setelah penyampaian materi, dimana peserta diperbolehkan mengajukan pertanyaan yang terkait materi dipandu oleh moderator dan peserta lain serta narasumber dipersilahkan untuk menanggapi pertanyaan.

3. Pemeriksaan haemoglobin awal

Pemeriksaan ini dilakukan dengan menggunakan alat tes haemoglobin sehingga dapat diketahui termasuk ke dalam kategori anemia atau tidak.

\section{PELAKSANAAN DAN HASIL}

Kegiatan Upaya Pencegahan Penyakit Anemia dengan Pemeriksaan Hemoglobin Awal pada Santri Pondok Pesantren Thawalib Sriwijaya Palembang dilaksanakan pada satu hari, yaitu pada hari Selasa tanggal 27 Oktober 2020, pukul 8.00 WIB - 11.00 WIB.

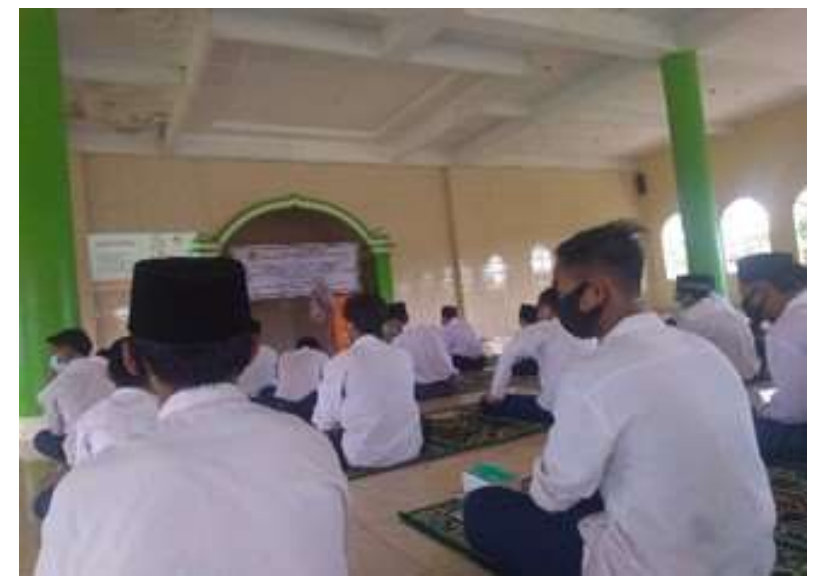

Gambar 1. Penyampaian materi tentang anemia Sumber: Dokumentasi Tim Pengabdian, 2020

Kegiatan dimulai dengan acara pembukaan yang dihadiri oleh kepala sekolah, guru dan para santri. Setelah itu dilakukan pemaparan tentang penyakit anemia pada 
remaja oleh pemateri. Pemaparan ini menjelaskan tentang epidemiologi, penyebab, tanda dan gejala, pencegahan penyakit anemia pada remaja. Pada pemaparan ini juga dijelaskan tentang prosedur pemeriksaan haemoglobin darah dengan menggunakan alat pemeriksaan hemoglobin.

Setelah pemaparan selesai, para peserta diberi kesempatan untuk melakukan sesi tanya jawab. Adapun beberapa pertanyaan yang diajukan oleh peserta antara lain:

1. Makanan apa yang sebaiknya dikonsumsi untuk mencegah penyakit anemia pada remaja?

2. Jika ditemukan gejala dan tanda yang sudah dipaparkan sebelumnya, apa yang sebaiknya dilakukan oleh penderita?

Setelah sesi diskusi selesai, kegiatan dilanjutkan dengan pemeriksaan hemoglobin darah peserta kegiatan. Peserta dipanggil satu per satu kemudian dilakukan pemeriksaan. Pemeriksaan hemoglobin dilakukan menggunakan alat tes hemoglobin dengan mengambil darah perifer (pada ujung jari) yang diletakkan pada strip hemoglobin, lalu dilihat nilai haemoglobin yang tertera pada alat tersebut.

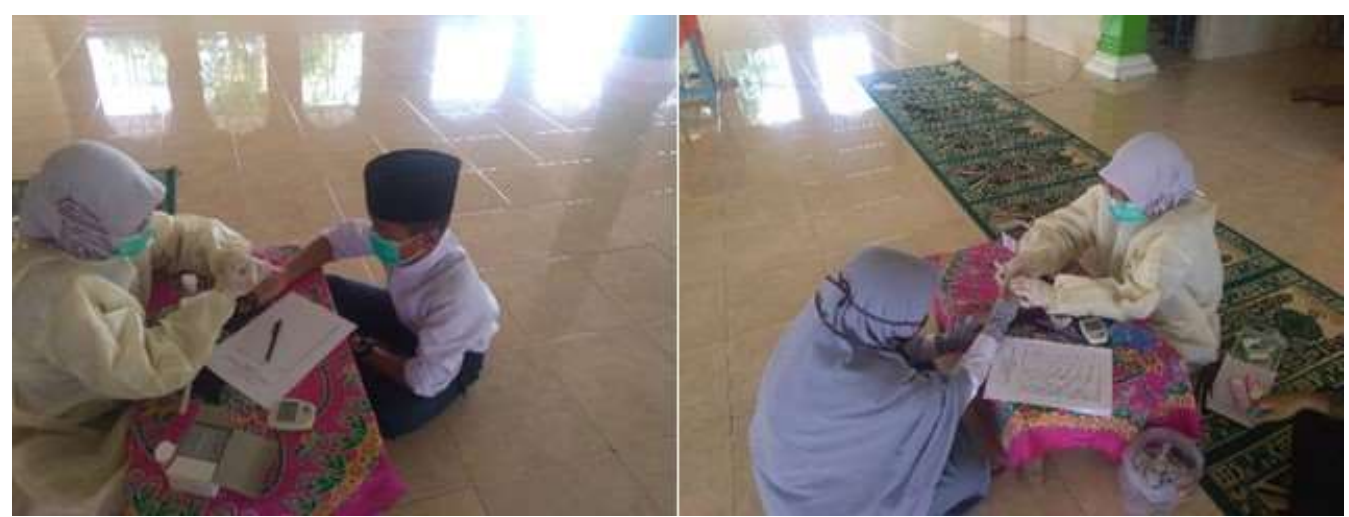

Gambar 2. Pemeriksaan haemoglobin darah

Sumber: Dokumentasi Tim Pengabdian, 2020

Pemeriksaan dilakukan pada 46 orang santri, yang terdiri dari 31 orang santri laki-laki (67\%) dan 15 orang santri perempuan (33\%) (Gambar 3). 


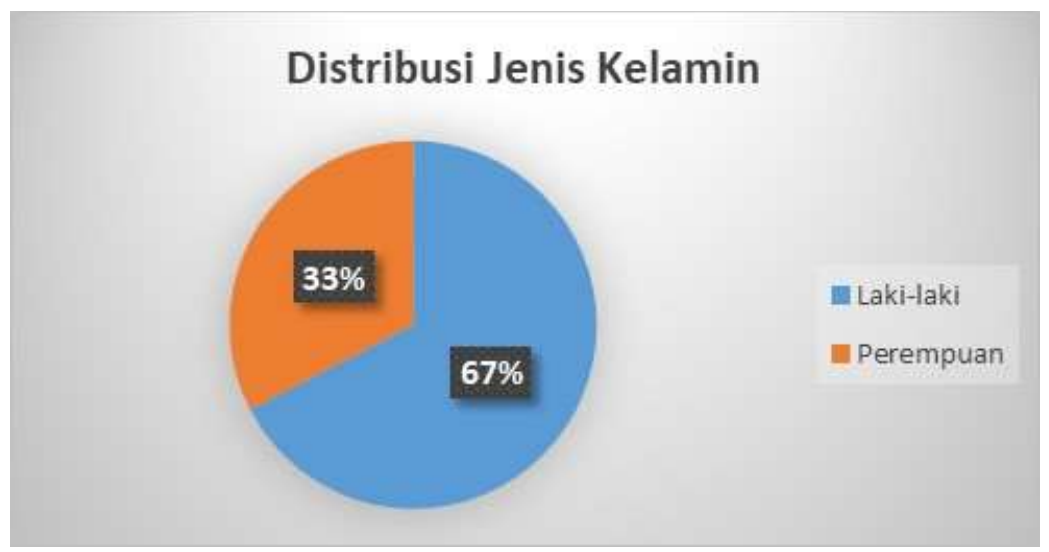

Gambar 3. Distribusi Jenis Kelamin

Sumber: Hasil Pengabdian, 2020

Rentang usia santri yang diperiksa yaitu antara 12-18 tahun. Usia yang paling banyak adalah usia 14 tahun (28\%), diikuti oleh usia 13 tahun (26\%), 15 tahun (17\%), 12 tahun (13\%), 16 tahun (9\%), 18 tahun (4\%), dan 17 tahun (2\%) (Gambar 4).

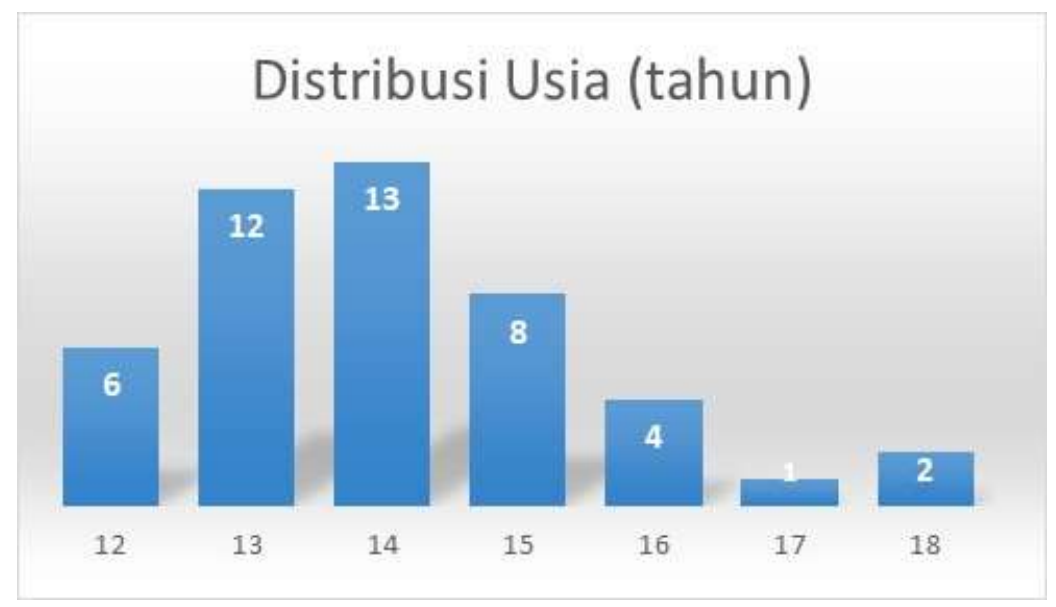

Gambar 4. Distribusi Usia

Sumber: Hasil Pengabdian, 2020

Dari hasil pemeriksaan hemoglobin didapatkan kadar haemoglobin darah pada rentang 10,1-19,9 g/dL. Pada santri laki-laki didapatkan sebanyak 13 orang $(42 \%)$ yang memiliki kadar haemoglobin $<13 \mathrm{~g} / \mathrm{dl}$ dan 18 orang (58\%) dengan kadar hemoglobin $>13 \mathrm{~g} / \mathrm{dl}$. Sedangkan pada santri perempuan didapatkan hanya 1 orang $(7 \%)$ yang memiliki kadar haemoglobin $<12 \mathrm{~g} / \mathrm{dl}$ dan 14 orang (93\%) dengan kadar haemoglobin $>12 \mathrm{~g} / \mathrm{dl}$ (Tabel 1). 
Tabel 1. Hasil pemeriksaan kadar hemoglobin

\begin{tabular}{cccc}
\hline No & Jenis Kelamin & Kadar Hemoglobin $(\mathrm{g} / \mathrm{dl})$ & Jumlah (orang) \\
\hline 1 & Laki-laki & $<13$ & 13 \\
& & $>13$ & 18 \\
\hline 2 & Perempuan & $<12$ & 1 \\
& & $>12$ & 14 \\
\hline & & & 46 \\
\hline
\end{tabular}

Sumber: Hasil Pengabdian, 2020

Santri Pondok Pesantren Thawalib Sriwijaya Palembang yang dilakukan pemeriksaan berusia antara 12-18 tahun, yaitu sebanyak 6 orang berusia 12 tahun (13\%), 12 orang berusia 13 tahun (26\%), 13 orang berusia 14 tahun (28\%), 8 orang berusia 15 tahun (17\%), 4 orang berusia 16 tahun (9\%), 1 orang berusia 17 tahun $(2 \%)$, dan 2 orang berusia 18 tahun (4\%) (Gambar 4). Hal ini sesuai dengan analisis situasi yang dilakukan sebelumnya.

Pada pemeriksaan hemoglobin ditemukan sebanyak 13 santri laki-laki (48\%) yang memiliki kadar hemoglobin $<13 \mathrm{~g} / \mathrm{dl}$ dan 1 santri perempuan $(7 \%)$ yang memiliki kadar hemoglobin $<12 \mathrm{~g} / \mathrm{dl}$. Berdasarkan klasifikasi WHO, hasil pemeriksaan menunjukkan gejala anemia jika kadar hemoglobin $<12 \mathrm{mg} / \mathrm{dl}$ pada wanita dan $<13$ mg/dl pada laki-laki (Cappellini and Motta, 2015). Hal ini berarti terdapat 14 santri (30\%) yang memiliki gejala anemia. Hasil ini hampir sama dengan data penelitian sebelumnya yaitu prevalensi anemia pada remaja di negara berkembang yaitu sekitar 27\% (Dugdale, 2001).

Penyebab anemia pada remaja di negara berkembang dapat diakibatkan oleh banyak faktor, yaitu kekurangan gizi (asam folat, zat besi, dan vitamin B12), infeksi (malaria dan infeksi cacing pada usus) dan penyakit kronis (Cheesbrough, 2006). Pada masa remaja, kebutuhan zat besi meningkat karena pertumbuhan yang pesat. Untuk meningkatkan penyerapan zat besi, kadar feritin menurun. Prevalensi anemia pada anak laki-laki pubertas diakibatkan oleh peningkatan fisiologis konsentrasi hemoglobin yang disebabkan oleh pematangan seksual serta penurunan kebutuhan setelah percepatan pertumbuhan selesai. Sedangkan pada anak perempuan, anemia terjadi karena adanya menarche dan ketidakteraturan menstruasi yang dapat menghentikan peningkatan konsentrasi hemoglobin sesuai usia (Balci et al., 2012).

Perubahan fisik dan fisiologis yang terjadi pada remaja meningkatkan kebutuhan nutrisi yang besar dan membuat lebih rentan terhadap kekurangan nutrisi. Remaja berisiko tinggi mengalami kekurangan zat besi dan anemia. Hal ini disebabkan oleh pertumbuhan pubertas yang cepat dengan peningkatan tajam pada massa tubuh tanpa lemak, volume darah, dan massa sel darah merah, yang meningkatkan kebutuhan zat besi untuk mioglobin di otot dan $\mathrm{Hb}$ dalam darah. Kebutuhan zat besi 
meningkat dua hingga tiga kali lipat dari tingkat pra-remaja 0,7-0,9 mg zat besi/hari menjadi sebanyak 1,37-1,88 $\mathrm{mg}$ zat besi/hari pada remaja laki-laki dan 1,40-3,27 mg zat besi/hari pada remaja perempuan (Tesfaye et al., 2015).

Anemia pada masa remaja menyebabkan berkurangnya kapasitas fisik dan mental, berkurangnya konsentrasi dalam pekerjaan dan prestasi pendidikan, serta menimbulkan masalah yang serius bagi masa depan ibu pada anak perempuan. Anemia pada remaja berhubungan dengan konsekuensi fungsional dari defisiensi zat besi. Hal ini sangat terkait dengan tingkat keparahan anemia. Ini menyebabkan penurunan resistensi terhadap infeksi, gangguan pertumbuhan fisik dan perkembangan mental, dan penurunan kebugaran fisik, kapasitas kerja, dan kinerja sekolah (Zeleke et al., 2020).

\section{PENUTUP}

Kegiatan pengabdian masyarakat terselenggara dengan baik dan berjalan lancar sesuai dengan rencana yang telah disusun serta antusiasme peserta juga sangat tinggi. Kegiatan dilanjutkan dengan pemeriksaan kadar hemoglobin dan ditemukan 14 santri (30\%) yang memiliki gejala anemia karena kadar hemoglobin di kurang dari normal..

\section{UCAPAN TERIMA KASIH}

Tim penulis mengucapkan terimakasih kepada Pengurus Pondok Pesantren Thawalib Sriwijaya Palembang dan seluruh santri yang terlibat aktif pada penyelenggaraan kegiatan pengabdian ini. Terimakasih kepada FK UNSRI atas pendanaan kegiatan pengabdian melalui Anggaran DIPA Fakultas Kedokteran Universitas Sriwijaya tahun 2020.

\section{DAFTAR PUSTAKA}

Balcı, Y. I., Karabulut, A., Gürses, D., \& Çövüt, I. E. (2012). Prevalence and risk factors of anemia among adolescents in Denizli, Turkey, Iranian journal of pediatrics, 22(1).

Briawan, D. (2014) Anemia: masalah gizi pada remaja wanita. Jakarta: ECG

Cappellini, M. D. \& Motta, I. (2015). Anemia in clinical practice-definition and classification: does hemoglobin change with aging?, in Seminars in hematology, pp. 261-269.

Cheesbrough, M. (2006) District laboratory practice in tropical countries (part 2). Cambridge university press.

Dugdale, M. (2001). Anemia, Obstetrics and gynecology clinics of North America. Elsevier, 28(2), pp. 363-382.

Ghaffar, F. and Waqar, F. (2018). Prevalence Of Iron Deficiency Anaemia In Young Adolescent Girls At University Of Peshawar. Pakistan Journal of Physiology, 14(3), pp. 33-36. 
Kementerian Kesehatan RI. (2018). Laporan Nasional Riskasdes. Available at: labdata.litbang.kemkes.go.id/ccount/click.php?id=19.

Permaesih, D. and Herman, S. (2005). Faktor-faktor yang mempengaruhi anemia pada remaja', Buletin Penelitian Kesehatan, 33(4 Des).

Suryani, D., Hafiani, R. and Junita, R. (2017). Analisis pola makan dan anemia gizi besi pada remaja putri Kota Bengkulu, Jurnal Kesehatan Masyarakat Andalas, 10(1), pp. $11-18$.

Tesfaye, M. et al. (2015). Anemia and iron deficiency among school adolescents: burden, severity, and determinant factors in southwest Ethiopia', Adolescent health, medicine and therapeutics. Dove Press, 6, p. 189.

World Health Organization. (2006). Adolcent Nutrition-A Review of The Stituation Selected South-East Asian Countries. Available at: http://www.who.int/nutrition/publications/schoolagechildren/SEA_NUT_163/e $\mathrm{n} /$.

World Health Organization and others. (2001). Iron deficiency anaemia assessment, prevention, and control: A guide for programme manager. WHO.

Zeleke, M. B. et al. (2020). Anemia and Its Determinants among Male and Female Adolescents in Southern Ethiopia: A Comparative Cross-Sectional Study', Anemia. Hindawi, Volume 2020. 